\title{
Tropical cyclone influence on the long-term variability of Philippine summer monsoon onset
}

\author{
Hisayuki Kubota ${ }^{*^{*}}$ D , Ryuichi Shirooka ${ }^{2}$, Jun Matsumoto ${ }^{2,3}$, Esperanza O. Cayanan ${ }^{4}$ and Flaviana D. Hilario ${ }^{4}$
}

\begin{abstract}
The long-term variability of Philippine summer monsoon onset from 1903 to 2013 was investigated. The onset date is defined by daily rainfall data at eight stations in the northwestern Philippines. Summer monsoons tended to start earlier in May after the mid-1990s. Other early onset periods were found during the 1900s, 1920s, and 1930s, and an interdecadal variability of summer monsoon onset was identified. Independent surface wind data observed by ships in the South China Sea (SCS) revealed prevailing westerly wind in May during the early monsoon onset period. To identify atmospheric structures that trigger Philippine summer monsoon onset, we focused on the year 2013, conducting intensive upper-air observations. Tropical cyclone (TC) Yagi traveled northward in the Philippine Sea (PS) in 2013 and triggered the Philippine monsoon onset by intensifying moist low-level southwesterly wind in the southwestern Philippines and intensifying low-level southerly wind after the monsoon onset in the northwestern Philippines. The influence of TC was analyzed by the probability of the existence of TC in the PS and the SCS since 1951, which was found to be significantly correlated with the Philippine summer monsoon onset date. After the mid-1990s, early monsoon onset was influenced by active TC formation in the PS and the SCS. However, the role of TC activity decreased during the late summer monsoon periods. In general, it was found that TC activity in the PS and the SCS plays a key role in initiating Philippine summer monsoon onset.
\end{abstract}

Keywords: Summer monsoon onset, Tropical cyclone, Long-term variability, Interdecadal variability, PALAU, Philippines

\section{Introduction}

The Philippines is an archipelago located in the western rim of the western tropical Pacific. There are distinct summer monsoons (local name Habagat) on the western side and winter monsoons (local name Amihan) on the eastern side of the country associated with the seasonal shift of major wind direction (Flores and Balagot 1969). The seasonal change of wind direction characterizes the climate phenomenon referred to as a "monsoon" (Ramage 1971). The thermal contrast between land and ocean contributes to this seasonal variation of winds in Asia (Murakami and Matsumoto 1994). During summer, moist southwesterly to westerly wind blows from the Arabian Sea through the Bay of Bengal, the South China

\footnotetext{
*Correspondence: hkubota@ep.sci.hokudai.ac.jp

${ }^{1}$ Faculty of Science, Hokkaido University, Kita 10 Nishi 8, Kita-ku, Sapporo 060-0810, Japan

Full list of author information is available at the end of the article
}

Sea (SCS), and the Philippine Sea (PS), bringing seasonal rainfall to India, the Indochina Peninsula, and the Philippines (Wang 2006). Therefore, seasonal wind (monsoon) is closely linked to the seasonal variation of rainfall; namely, the Asian summer monsoon system is characterized by seasonal wind and rainfall. The Asian summer monsoon has several subsystems. Over the oceanic region of the PS including the Philippine region, the western North Pacific (WNP) summer monsoon dominates (Murakami and Matsumoto 1994).

Agriculture and other water resources on land rely strongly on when the seasonal rainfall starts and the amount of seasonal rainfall. Therefore, the starting date of the summer monsoon is a critical issue. The onset of the WNP summer monsoon, including that in the Philippine region, has been the focus of several studies. Rainfall data were used to define the Asian monsoon onset (Matsumoto 1997; Akasaka et al. 2007). Some studies 
(Tanaka 1992; Lau and Yang 1997; Wang and LinHo 2002) used satellite data of outgoing longwave radiation (OLR) to define an index of convective activity. Kubota et al. (2005) used satellite-based wind data to identify the change of wind direction to define the monsoon onset. These studies determined that the Philippine summer monsoon starts around May to early June with the arrival of moist low-level westerly wind and the start of active convection in climatology. However, both monsoon activity and onset date have interannual and interdecadal variability.

The summer monsoon activity over the WNP has interannual variability associated with the El Niño-Southern Oscillation (ENSO; Ropelewski and Halpert 1987). Rainfall tends to increase during the summer (June-August) of the El Niño developing year (Lyon et al. 2006; Kubota and Wang 2009). However, rainfall decreases because of the eastward shift of the tropical cyclone (TC) track in autumn (September-November; Saunders et al. 2000; Lyon et al. 2006; Lyon and Camargo 2008; Kubota and Wang 2009). The summer monsoon activity of the subsequent El Niño decaying year becomes weak, a phenomenon which is associated with the ENSO influence on sea surface temperature (SST) anomalies in the Indian Ocean (IO; Xie et al. 2009).

The summer monsoon onset date over the WNP tends to be delayed during the El Niño decaying year, as revealed by the interannual variability of summer monsoon activity (Tanaka 1997). The decadal variability of summer monsoon onset in the Philippines and SCS includes early onset during the late twentieth century, as reported by Akasaka (2010) and Kajikawa and Wang (2012). Akasaka (2010) suggested that the early approach of an easterly wave might trigger an early monsoon onset in the Philippines. Kajikawa and Wang (2012) noted that the enhancement of intraseasonal variability of convection and TC activity is important for early monsoon onset in the SCS after the mid-1990s. Both studies highlighted the potential impact of recent sea surface temperature (SST) warming in the SCS. However, both studies focused on recent 30- to 50year variability, but SST in the SCS has undergone multitime-scale variability over the past 138 years (Yang et al. 2015). The data used in these monsoon onset studies are not extensive enough to determine how recently observed early monsoon onsets are connected to other longer timescale variability.

Recently, we collected Philippine rainfall data from the late nineteenth century (Chowdary et al. 2012; Villafuerte et al. 2014) and found that the northwestern Philippine station rainfall has been strongly correlated with the Pacific-Japan (PJ) pattern for more than 100 years (Kubota et al. 2016). The PJ pattern is a dominant teleconnection of interannual variability in the WNP monsoon and East Asian summer monsoon (Nitta 1987) and is correlated to the preceding boreal winter ENSO (Chang et al. 2000a, b; Wang et al. 2000). The occurrence of TC over the WNP during summer is also correlated with the PJ pattern. The relationship between the PJ pattern and ENSO and TC activity was modulated on the interdecadal time scale. It has not been discussed how the interdecadal modulation of the WNP summer monsoon and its related phenomena, such as TC, affect the variability of the Philippine monsoon onset date. In this study, we investigate the long-term variability of the Philippine summer monsoon onset date using rainfall data covering more than 100 years.

The atmospheric structures that cause Asian summer monsoon onset have been investigated using a reanalysis dataset that includes the Philippine region (Wang 2006). The quality of the three-dimensional reanalysis dataset strongly depends on the availability of upper-air observations (Hattori et al. 2016). However, in the Philippines, upper-air observations were no longer carried out throughout the year after the US Clark Air Base was closed because of the eruption of Mt. Pinatubo in 1991. Here, we report the results of intensive upper-air observations in Laoag, Cebu Mactan, and Puerto Princesa in the Philippines from May to August 2013 (Fig. 1). The year 2013 was the first summer that comprehensive upper-air observations were conducted in the Philippines since 1991 (Fig. 2). Upper-air observations that include intensive observations provide essential data for compiling a vertical profile of the atmosphere and are assimilated to create the reanalysis dataset. The inclusion of intensive observations in the reanalysis dataset allows us to capture qualitatively which atmospheric structures trigger Philippine summer monsoon onset.

\section{Methods}

Continuous rainfall observations in the Philippines were started in Manila in 1865 by Jesuits in the Manila Observatory (Deppermann 1939; Udias 1996). The Manila Observatory expanded the number of weather stations in the Philippines in the 1880s. However, many of these observational data are now missing. The observations of the Observatorio Meteorológico de Manila made by Spanish meteorologists were collected from 1891 to 1900; unfortunately, the quality of the rainfall data is questionable, except for the data in Manila. The Monthly Bulletin of the Philippine Weather Bureau was published from January 1901 to August 1940. In 1903, the Philippine Weather Bureau expanded the number of weather stations in the Philippines, again under the direction of the Jesuits of the Manila Observatory, along with American meteorologists (Sola 1903). From September 1940, weather observations were obtained by Japanese meteorologists. Daily rainfall data exist for September and October 1942; September, October, and 


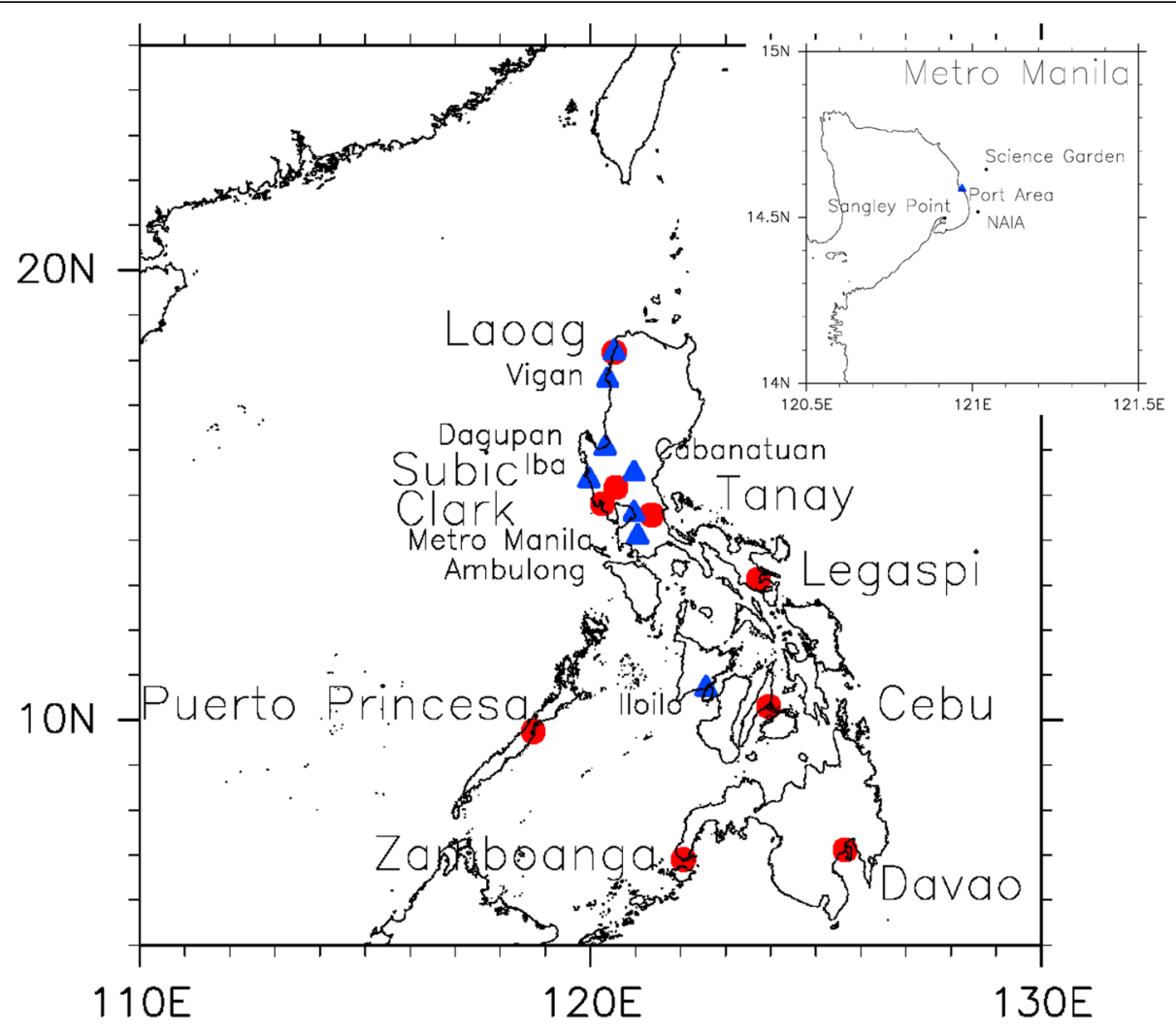

Fig. 1 Locations of observation stations. Upper-air observation stations (red dots with large station name) and surface rainfall observation stations (blue triangles with small station name) used to define Philippine monsoon onset

December 1943; and January 1944 (Kobayashi and Yamamoto 2013). After 1949, the Philippine Atmospheric Geophysical and Astronomical Services Administration (PAGASA) operated the observations in the Philippines. The homogeneity of the station rainfall data was tested by the R-based RHtests_dlyPrcp software (Wang and Feng 2013). If any discontinuity was detected, we adjusted the data based on the quantile-matching algorithm of the RHtests_dlyPrcp software (Wang et al. 2010).

PAGASA defined Philippine summer monsoon onset using eight stations in the northwestern Philippines (Fig. 1; Cayanan 2010). When more than half of the stations satisfied the following criteria during May-July, PAGASA defined it as a summer monsoon onset:

1. Five-day total rain being $25 \mathrm{~mm}$ or more;

2. At least three rainy days, each having $5 \mathrm{~mm}$ or more in a 5 -day period.

3. The first day of the 5-day period satisfying both 1 and 2 is taken as the beginning of the onset.

They defined Metro Manila as a combination of four stations: Science Garden, Port Area, NAIA (Ninoy Aquino International Airport), and Sangley Point. When three of the four stations satisfied the monsoon onset criteria, Metro Manila was considered to have satisfied the criteria. In this study, we follow these Philippine summer monsoon onset criteria using the rainfall data at eight stations. Port Area is the oldest station in Manila. The other three stations of NAIA, Science Garden, and Sangley Point started observations in 1951, 1961, and 1974, respectively. Therefore, we used Port Area as representative of Metro Manila. The official PAGASA summer monsoon onset date was determined by considering not only the rainfall criteria but also other factors like wind data after 1979. Since the other factors may change over time because of the development of observation technology, it is difficult to reproduce these factors for the past. In this study, we used the same criteria as PAGASA with rainfall data from eight stations to identify the monsoon onset. As a result, the summer monsoon onset dates may differ between our study and the official PAGASA announcements.

The International Comprehensive Ocean-Atmosphere Dataset (ICOADS; Woodruff et al. 2011) based on monthly ship observations dataset over the SCS is used for the period from 1901 to 2007 (Yang et al. 2015). These data are available at $2^{\circ}$ resolution along the SCS in the meridional direction, where the monthly SST data cover more than $80 \%$ of the total months during the 


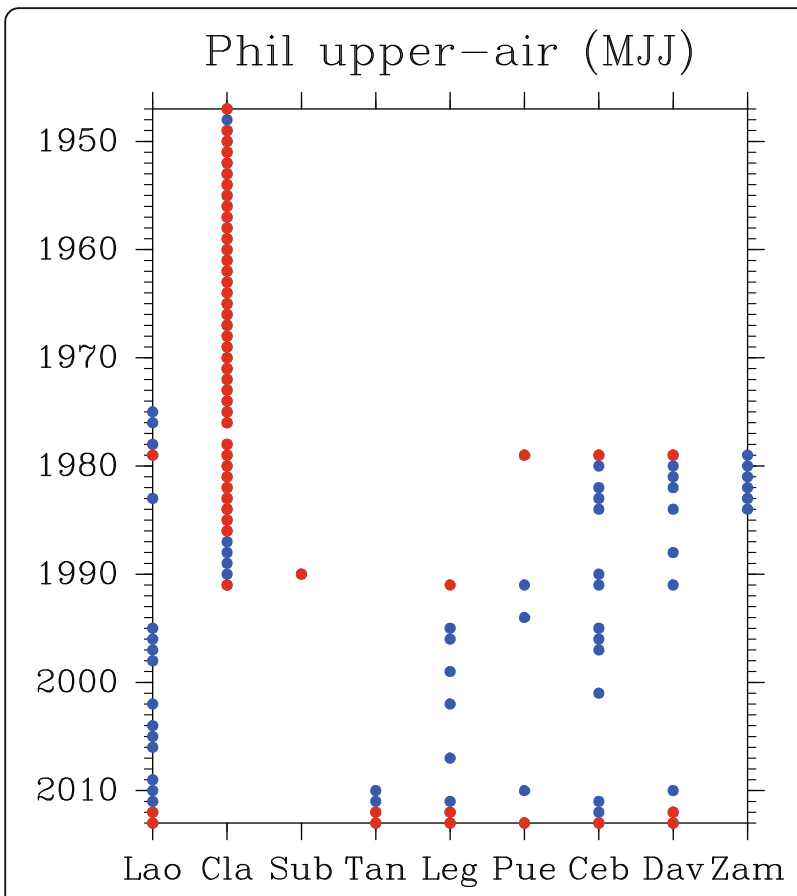

Fig. 2 Availability of upper-air observations. More than half of the period of May to July, upper-air observation is conducted at $00 \mathrm{Z}$ or at both $00 Z$ and $12 Z$-i.e., once or twice a day, are colored in blue and red respectively. The measurement stations Laoag (Lao), Clark air base (Cla), Subic (Sub), Tanay (Tan), Legaspi (Leg), Puerto Princesa (Pue), Cebu (Ceb), Davao (Dav), and Zamboanga (Zam) are shown along the $x$-axis

whole period (Fig. 1 of Yang et al. 2015). The ICOADS surface wind speed has a noticeable upward trend due to an increase in anemometer height during the twentieth century (Tokinaga and Xie 2011). We use zonal wind data and also consider the wind direction along the SCS in this study, which is not affected by the artificial change in the observation data. The TC best track data from the Joint Typhoon Warning Center (JTWC) and the Japan Meteorological Agency (JMA) are used. The ENSO index is defined using Niño 3.4 and the Hadley Center Global Sea Ice Sea Surface Temperature (HadISST) data (Rayner et al. 2003).

PAGASA carried out upper-air observations at eight stations (from the north: Laoag, Subic, Tanay, Legaspi, Puerto Princesa, Cebu Mactan, Davao, and Zamboanga) in the Philippines (Fig. 1). Data are obtained from the Integrated Global Radiosonde Archive (Durre et al. 2006). Upper-air observations in the Philippines were started in 1947 by the US Clark Air Base staff (Fig. 2). Unfortunately, continuous observations stopped in 1991 because of the eruption of Mt. Pinatubo. Weather balloons were launched once a day at other upper-air observation stations. However, they were interrupted frequently because of an insufficient supply of sensors until 2012. Upper-air observations in the Subic and
Zamboanga stations were performed only for a short period. We conducted intensive upper-air observations in Laoag, Puerto Princesa, and Cebu Mactan in collaboration with PAGASA during the Pacific Area Long-term Atmospheric observation for the Understanding of climate change (PALAU) 2013 observation project. At the station of Cebu Mactan, upper-air observations were conducted twice a day from May 1 to August 29, 2013, except for during June 1-30, 2013, when they were conducted four times a day. At the Laoag and Puerto Princesa stations, observations were conducted twice a day from June 1 to July 31, 2013. The Japanese 55-year reanalysis dataset (JRA55; Ebita et al. 2011) on a $1.25^{\circ}$ grid was used to obtain three-dimensional structures of wind and moisture. Upper-air observation provides the most useful data for developing a vertical profile of the atmosphere, and these upper-air observations, including our intensive observations, are assimilated into the reanalysis dataset using the Global Telecommunications System.

\section{Results \\ Climatology of the Philippine monsoon}

Figure $3 \mathrm{a}, \mathrm{b}$ shows the climatology of monthly rainfall distributions along the western stations of the Philippines during 1977-2009. Rainfall increased from June to October north of $10^{\circ} \mathrm{N}$, associated with the summer monsoon. Rainfall at all western stations increased or decreased at the same time. However, rainfall at the eastern Philippine stations increased in October from the northern station of Aparri, propagating southward in November and reaching a maximum in January at the southern station of Hinatuan, associated with the winter monsoon (Fig. 3c, d) of the winter monsoon occurred in December in northern Luzon Island and tended to be delayed moving southward. At the southern station in Hinatuan, withdrawal of the winter monsoon occurred in March. However, a classic Philippine monsoon study showed the winter monsoon continued until March at all stations on the eastern side of the Philippines by considering the northeasterly wind direction (Flores and Balogot 1969). Northeasterly wind prevailed throughout winter from north to south at the eastern stations (e.g., Aparri, Legaspi, and Surigao). However, rainfall amounts reached a minimum in February and March in Aparri in northern Luzon. This indicates that the winter monsoon changed its structure in the second half of the winter monsoon season in Luzon Island in the northern Philippines, with less rainfall under northeasterly monsoon wind conditions. Flores and Balogot (1969) defined a unified climatology of the Philippine winter monsoon structure but did not mention the difference in meridional rainfall structures. The southern-most station, Davao, did not show a clear 

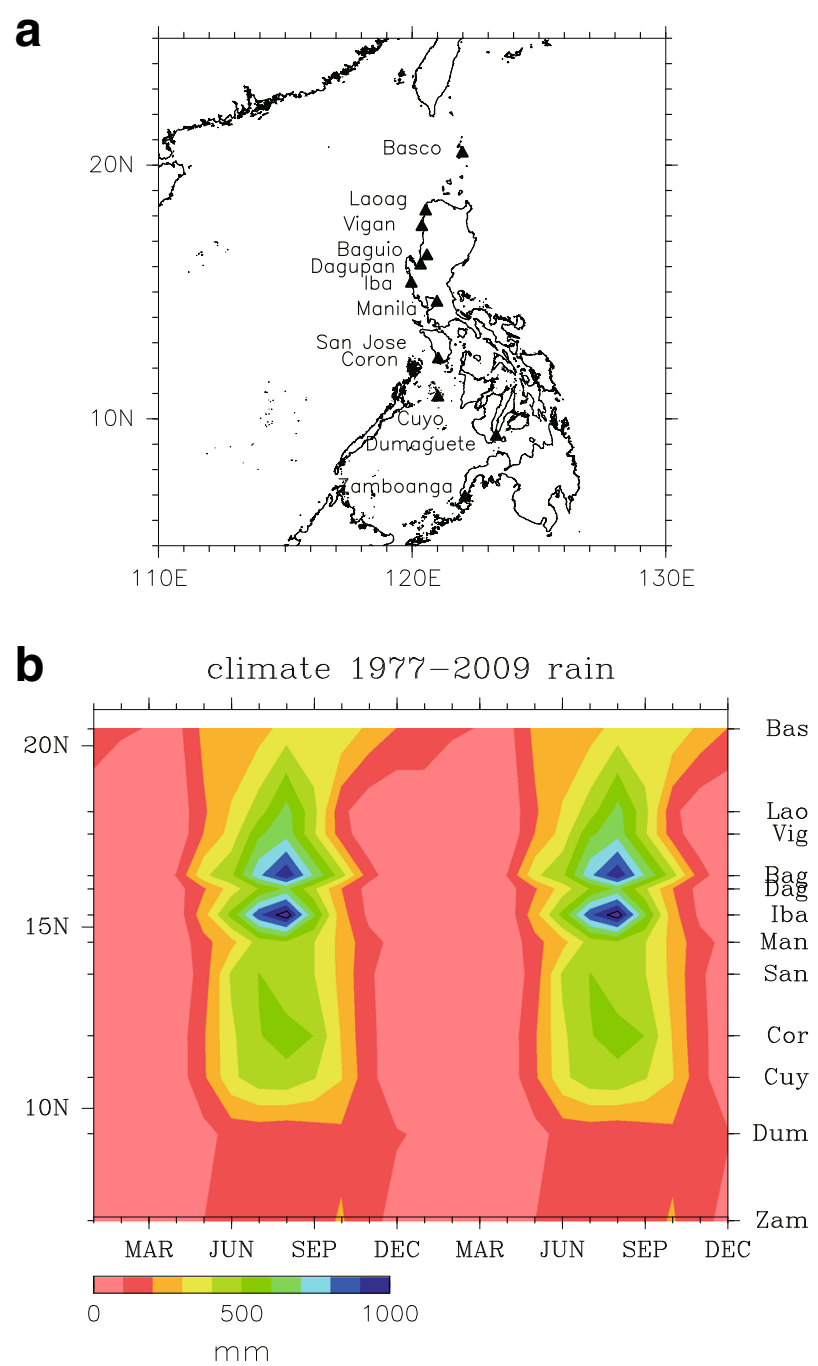

C
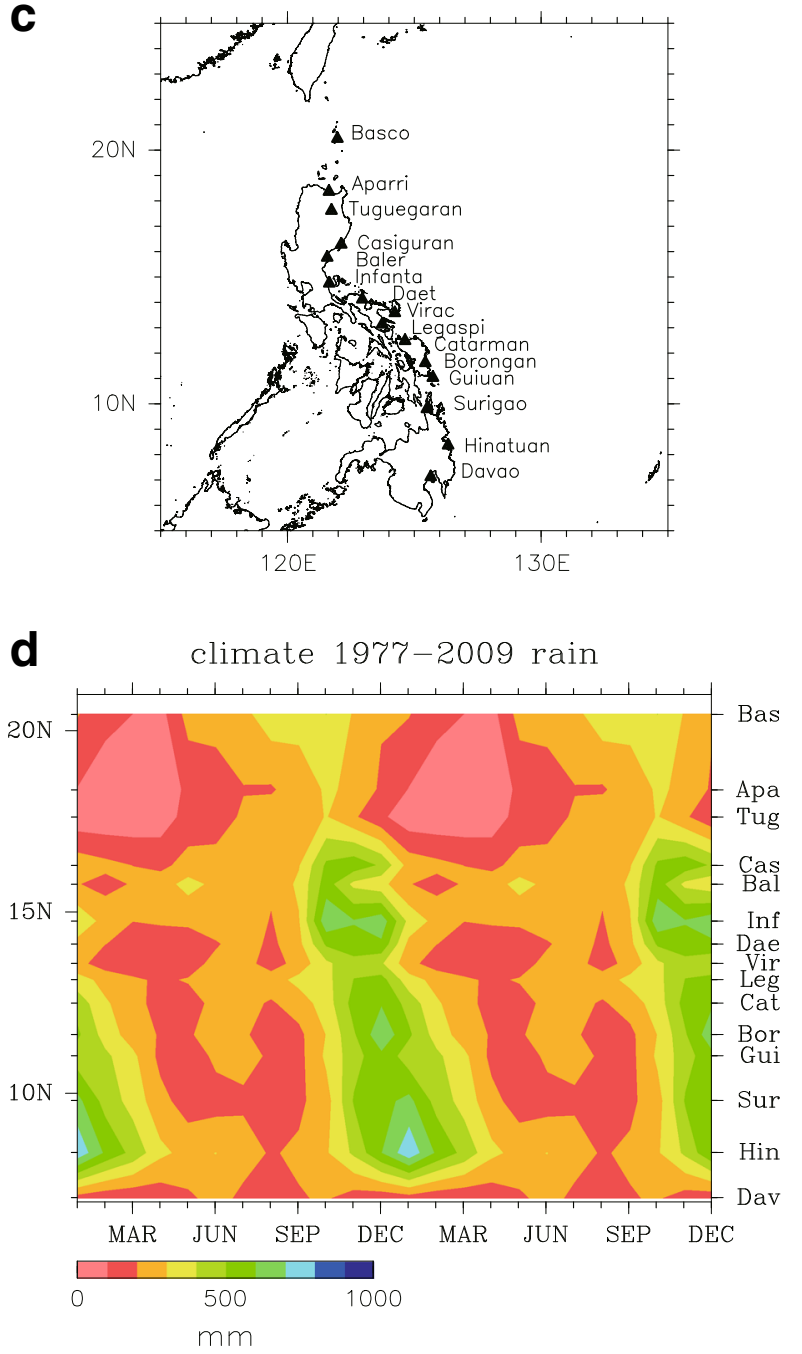

Fig. 3 Climatology of the western and eastern sides of the Philippines rainfall. a, c Station locations and $\mathbf{b}$, $\mathbf{d}$ climatology of monthly rainfall distribution along the western and eastern sides of the Philippines during the period 1977-2009

winter rainfall maximum. The structure of summer monsoon onset is the focus of the following section.

\section{Long-term variability of Philippine summer monsoon onset}

An increase in rainfall in the northwestern Philippines associated with moist southwesterly wind indicates the onset of a Philippine summer monsoon. Here, we use rainfall data from eight stations in the northwestern Philippines to define the Philippine summer monsoon onset, according to the PAGASA rainfall criteria, and expand the study period to the past 100 years. Figure 4 shows daily rainfall during 1901-2013 averaged over the eight northwest Philippine stations used to define the summer monsoon onset from 1903 onward. Rainfall increased around May to June and decreased around October to November. The summer monsoon onset dates are indicated by triangles. During 1941-1950, rainfall data were missing from most of the stations, primarily due to the occurrence of the Second World War.

Figure 5a shows a time series of the summer monsoon onset dates from 1903 to 2013. After the mid-1990s, the onset date tended to be earlier, and the monsoons started in May. Such early onset dates after the mid1990s were similarly reported in Akasaka (2010) and Kajikawa and Wang (2012). The long-term dataset that we used in this study further reveals other early onsets that occurred in the 1900s and from the 1920s to the 1930s, suggesting an interdecadal variability of the Philippine summer monsoon onset. After the start of the Philippine summer monsoon, the low-level wind direction shifts to westerly over the SCS (e.g., Puerto Princesa in the SCS, Fig. 8a). This suggests that when the summer monsoon starts in May, a monthly averaged westerly 

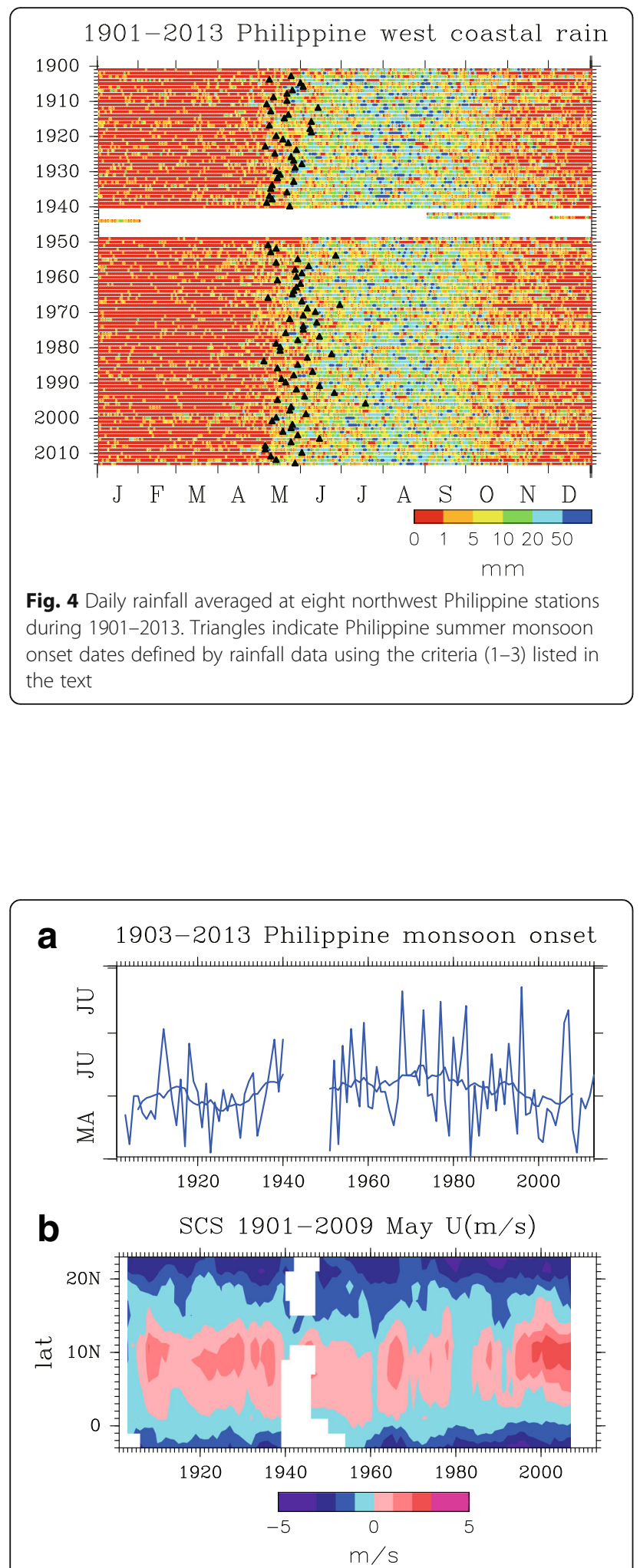

Fig. 5 Philippine summer monsoon onset date and surface zonal wind in May along the South China Sea. Time series of a Philippine summer monsoon onset date from 1903 to 2013 and b monthly surface zonal wind in May along the South China Sea from 1901 to 2007. Thick lines indicate an a 11-year or b 5-year running mean wind prevails near the surface (Fig. 6a). However, when the summer monsoon starts in June, the surface zonal wind component remains easterly or very weak in May (Fig. 6b). Figure 5b shows the monthly surface zonal wind along the SCS in May from 1901 to 2007. After the 1990s, strong westerly wind appears around $5^{\circ} \mathrm{N}-14^{\circ} \mathrm{N}$, associated with early summer monsoon onset. However, during the 1950 s to the early 1990s, the surface zonal wind was weakly westerly or easterly. This is consistent with the results of late summer monsoon onset in June defined by the rainfall data. It is worth noting that the westerly wind was also strong around $10^{\circ} \mathrm{N}$ around 1910 and during the 1920s and 1930s in May, which is consistent with the early summer monsoon onset seen in Fig. 5a.

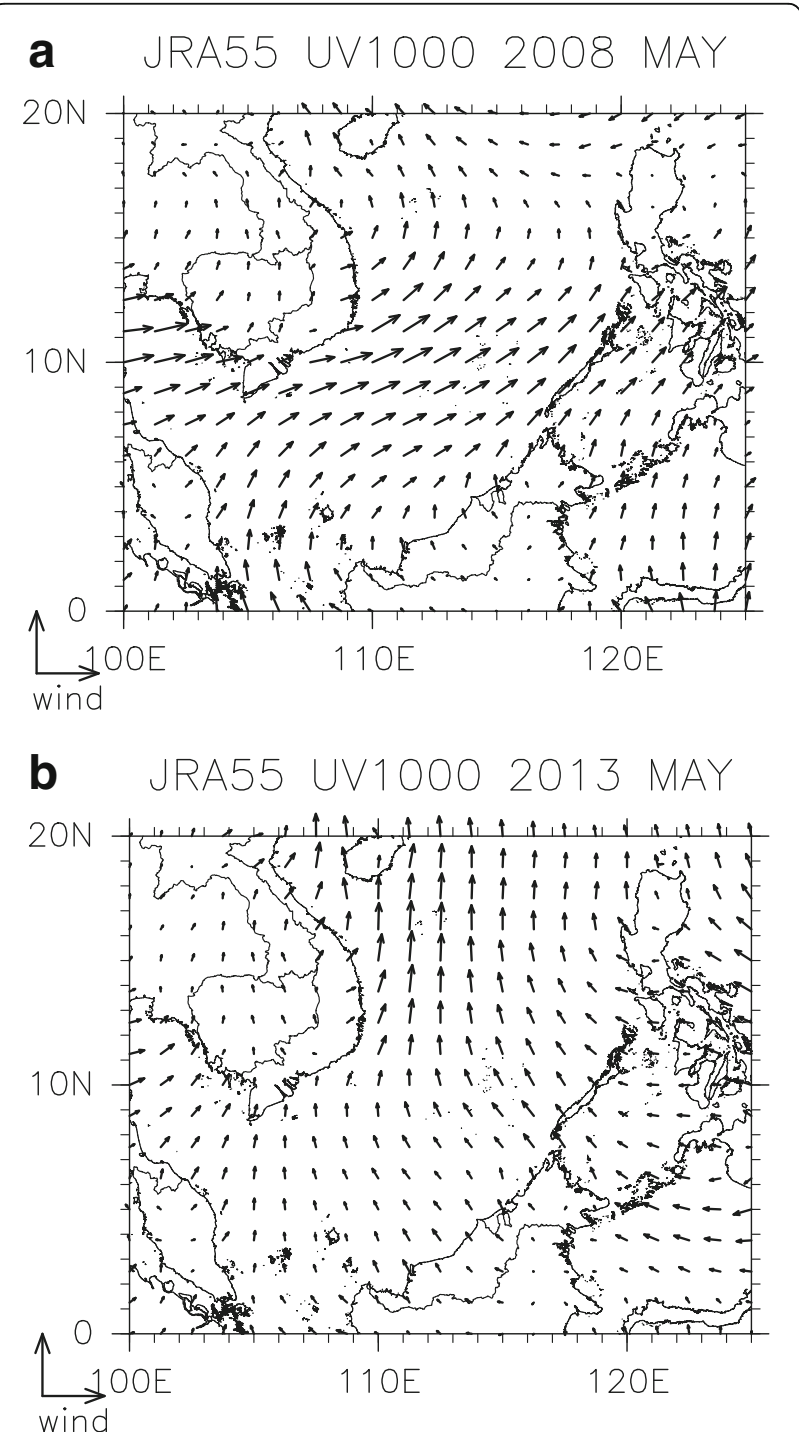

Fig. 6 Monthly averaged horizontal wind at $1000 \mathrm{hPa}$ in May in a 2008 and b 2013. Unit vectors represent $12.5 \mathrm{~m} / \mathrm{s}$ 
1Earlier studies have shown the strong influence of the ENSO on Philippine summer monsoon rainfall, which increases during the summer of El Niño developing years (Lyon et al. 2006; Kubota and Wang 2009) and decreases during the summer of the following El Niño decaying year (Xie et al. 2009). The correlation between Philippine summer monsoon rainfall and the ENSO also shows interdecadal variability (Chowdary et al. 2012). However, the Philippine summer monsoon onset date was delayed during El Niño decaying years only from around the 1970s to the 1980s (Fig. 7). Tanaka (1997) mentioned the delay of WNP summer monsoon onset during this high-correlation period around the 1970s to the 1980s. The correlations in other periods were insignificant. In summary, the summer monsoon onset date has been weakly correlated to the ENSO during the past 100 years. The PAGASA official summer monsoon onset date has also a weak correlation with the ENSO since the 1990s (not shown).

\section{Case study of 2013 Philippine summer monsoon onset}

What caused the interdecadal variability of Philippine summer monsoon onset? Unfortunately, the accuracy of atmospheric structures around the Philippines in the reanalaysis data has decreased since 1991 due to a lack of upper-air observations. Here, we use intensive upperair observations in 2013 in the Philippines to discuss the atmospheric factors responsible for triggering summer monsoon onset and then compare the case of 2013 to the past in the following subsections.

We focus on the change in atmospheric structure during Philippine summer monsoon onset in 2013 using intensive upper-air observations, which are included in the reanalysis data. Using the locally defined rainfall-based criteria for declaring the summer monsoon onset (see the "Methods" section), the Philippine summer monsoon started on June 9, 2013. Figure 8a shows the time series of upper-air observations and rainfall at Puerto Princesa in the southwestern Philippines before and after summer monsoon onset. The layers of relative humidity greater

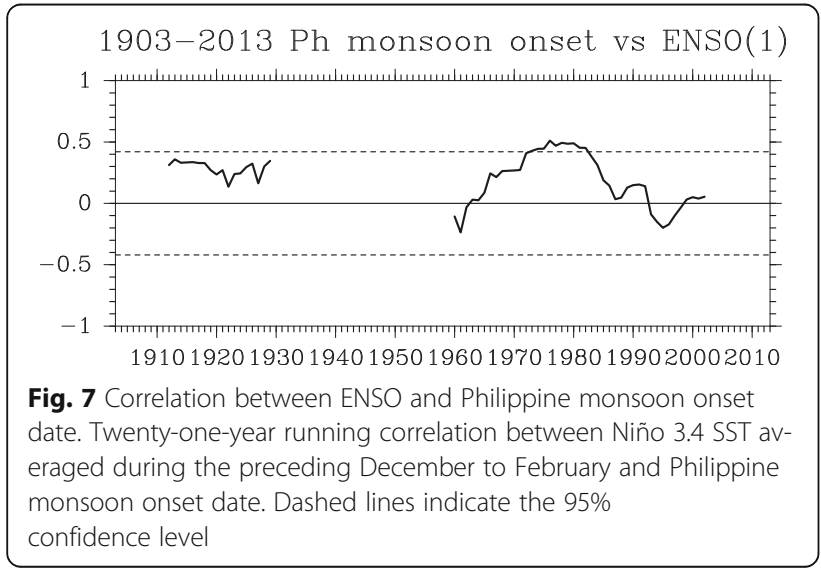

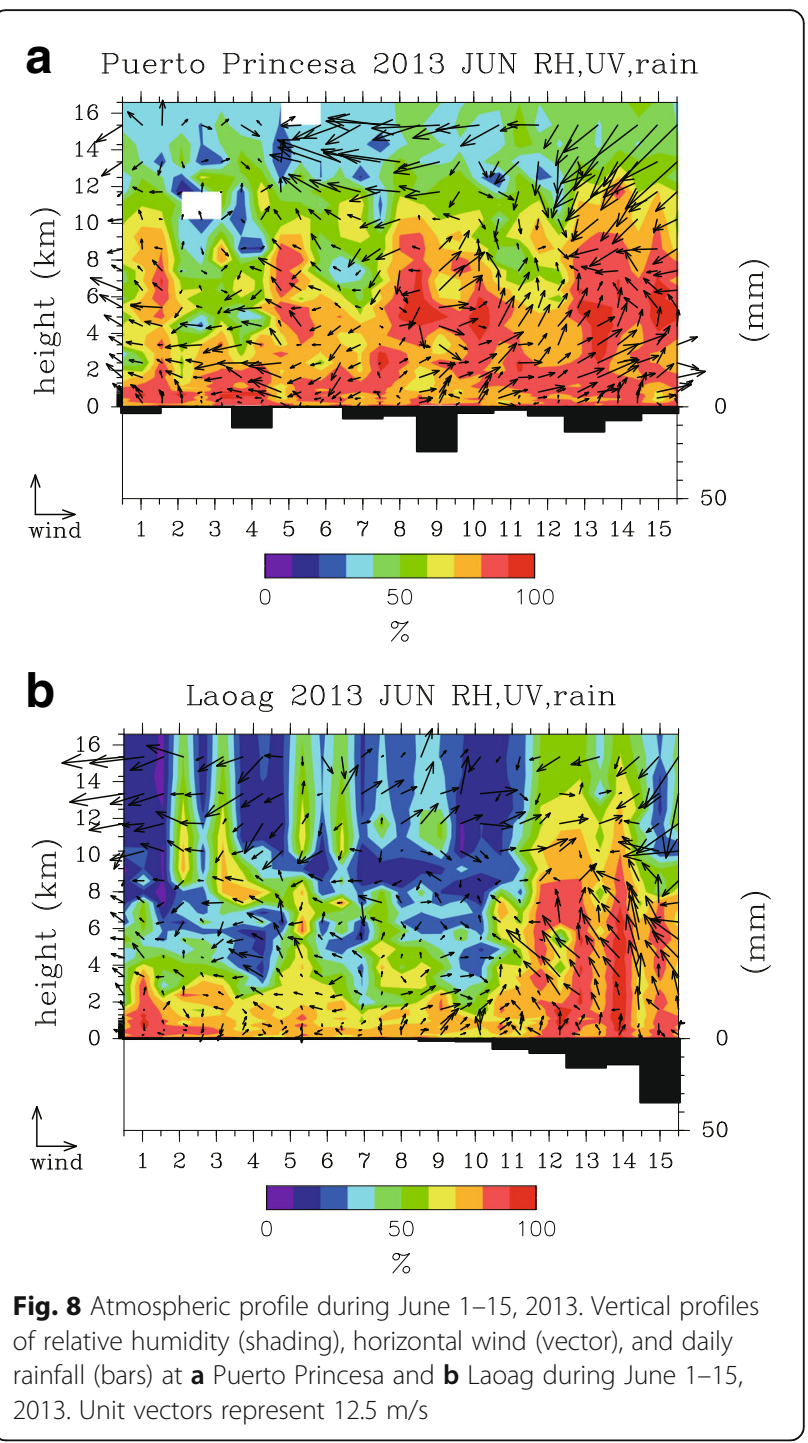

than $70 \%$ in the troposphere gradually expand from the lower troposphere over 7 days before the monsoon onset and are associated with rainfall events. Wind direction clearly shifts from northeasterly to southwesterly below $8 \mathrm{~km}$ after the monsoon onset on June 9. The arrival of moist southwesterly wind in the lower troposphere is associated with the large-scale seasonal migration of lowlevel convergence and activated the Asian summer monsoon in the Philippines (Wang 2006). However, different atmospheric structures were present before and after the monsoon onset in the northern Philippines. Figure 8b shows the time series of upper-air observations and rainfall at Laoag in the northwestern Philippines. It was very dry in the mid and upper troposphere before the monsoon onset. The layers of relative humidity greater than $70 \%$ suddenly increased up to $11 \mathrm{~km}$ and became wet and unstable from June 11 . The shifts in wind direction before and after the monsoon onset differed from 
those in the southwestern Philippines. Low-level southerly wind prevailed after the monsoon onset. In this study, we defined the summer monsoon onset using the northwestern Philippines rainfall data. Summer monsoon rainfall increased at the same times in the western Philippines (Fig. 3b). However, the time required for the moistening process to cause the lower to middle troposphere to become wet and unstable differs between the northern and southern Philippines.

The vertical profile of relative humidity and horizontal wind from the JRA55 reanalysis data, which were assimilated by upper-air observation data, are plotted in Fig. 9 including the same location of Puerto Princesa and Laoag during the same period as in Fig. 8. Wind direction changes associated with monsoon onset are consistent with upperair observations. However, the JRA55 data showed unrealistically high relative humidity in the wet layers, especially above $12 \mathrm{~km}$ and below $1 \mathrm{~km}$, during the analysis period in both regions. This represents wet bias in the upper

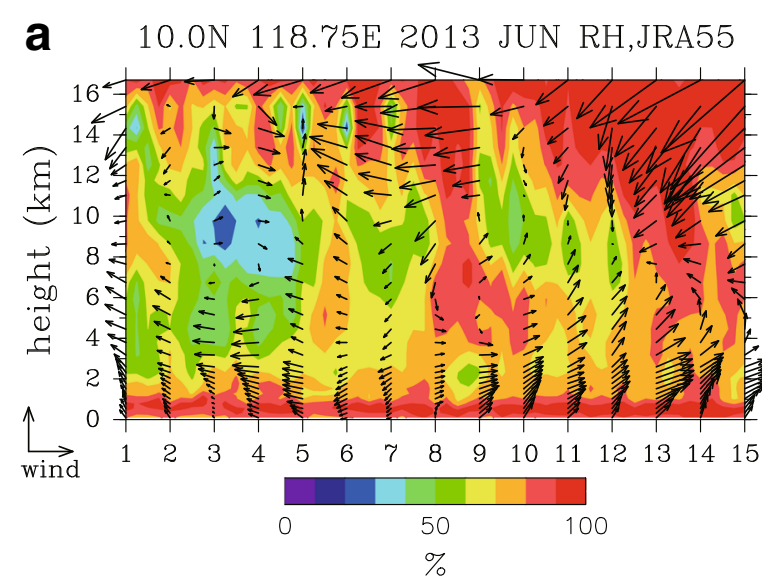

b $\quad 18.75 \mathrm{~N} \quad 120.0 \mathrm{E} 2013$ JUN RH,JRA55

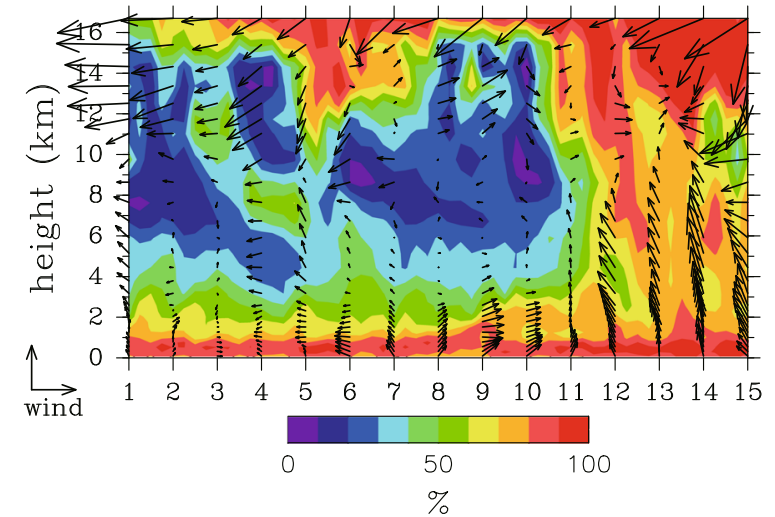

Fig. 9 Atmospheric profile by JRA55 during June 1-15, 2013. Same as Fig. 8 but for JRA55 relative humidity and wind at a $10.0^{\circ} \mathrm{N}$, $118.75^{\circ} \mathrm{E}$ (including Puerto Princesa) and $\mathbf{b} 18.75^{\circ} \mathrm{N}, 120.0^{\circ} \mathrm{E}$ (including Laoag) troposphere and near the surface in the JRA55 dataset. However, lower troposphere JRA55 data well capture the increase of relative humidity and are consistent with in situ observational data. The horizontal distribution of the wind and water vapor at $850 \mathrm{hPa}$ (about $1.5 \mathrm{~km}$ ) from the JRA55 data are discussed below.

The horizontal structures of water vapor mixing ratio and wind at $850 \mathrm{hPa}$ before and after the monsoon onset are shown in Fig. 10. Tropical cyclone (defined as an intensity of tropical storm exceeding $34 \mathrm{kt}$ maximum wind speed and hereafter referred to as TC) Yagi (1303) was generated at 12 UTC (coordinated universal time) on June 8, 2013, and traveled northward in the PS (Fig. 10a-e). As TC Yagi developed during June 8-9, moist southwesterly wind from the SCS passed over the Philippines and fed into TC Yagi (Fig. 10b, c). While TC Yagi traveled northward, the wind direction shifted from westerly to southerly in the northern Philippines. Figure 11 presents a cross section along the west Philippines $\left(117.5^{\circ} \mathrm{E}-120.0^{\circ} \mathrm{E}, 5^{\circ} \mathrm{N}-20^{\circ} \mathrm{N}\right.$,) for the period June $5-14$. Water vapor mixing ratio increased in the southern part of the cross section as the westerly wind intensified and moisture was transported northward, concurrently with the wind direction shift to southerly in the northern part of the cross section, after the monsoon onset. This suggests that in situ observations in Puerto Princesa at the southern Philippines station and in Laoag at the northern station, where we carried out intensive upper-air observations, can capture representative atmospheric structure changes in the south and north Philippines before and after the summer monsoon onset. The TC induced the moist southwesterly wind and activated the Philippine summer monsoon. The arrival of a TC is one of the major contributors to Philippine summer monsoon rainfall (Kubota and Wang 2009; Chen et al. 2010). Even if a TC does not make landfall in the Philippines, it can still enhance southwesterly flow and activate Philippine summer monsoon rainfall (Cayanan et al. 2011).

\section{Existence of tropical cyclones during the Philippine summer monsoon onset}

As demonstrated in the previous section, the passage of a TC over the PS played an important role in the Philippine summer monsoon onset in 2013. We then investigated whether a TC existed within the area comprising the PS and the $\mathrm{SCS}\left(100^{\circ} \mathrm{E}-140^{\circ} \mathrm{E}, 0^{\circ} \mathrm{N}-20^{\circ} \mathrm{N}\right.$; the area bounded by dashed lines in Fig. 10c) during the Philippine summer monsoon from 1951 to 2013. We also included tropical depressions that developed into TC within 2 days after the summer monsoon onset date. The existence of TC during the summer monsoon onset from 1951 to 2013 is shown in Fig. 12 (labeled "T" in Fig. 12). To explore the influence of TC on Philippine summer monsoon onset, we obtain the probability of TC existence (PTCe) during summer monsoon onset, expressed as 

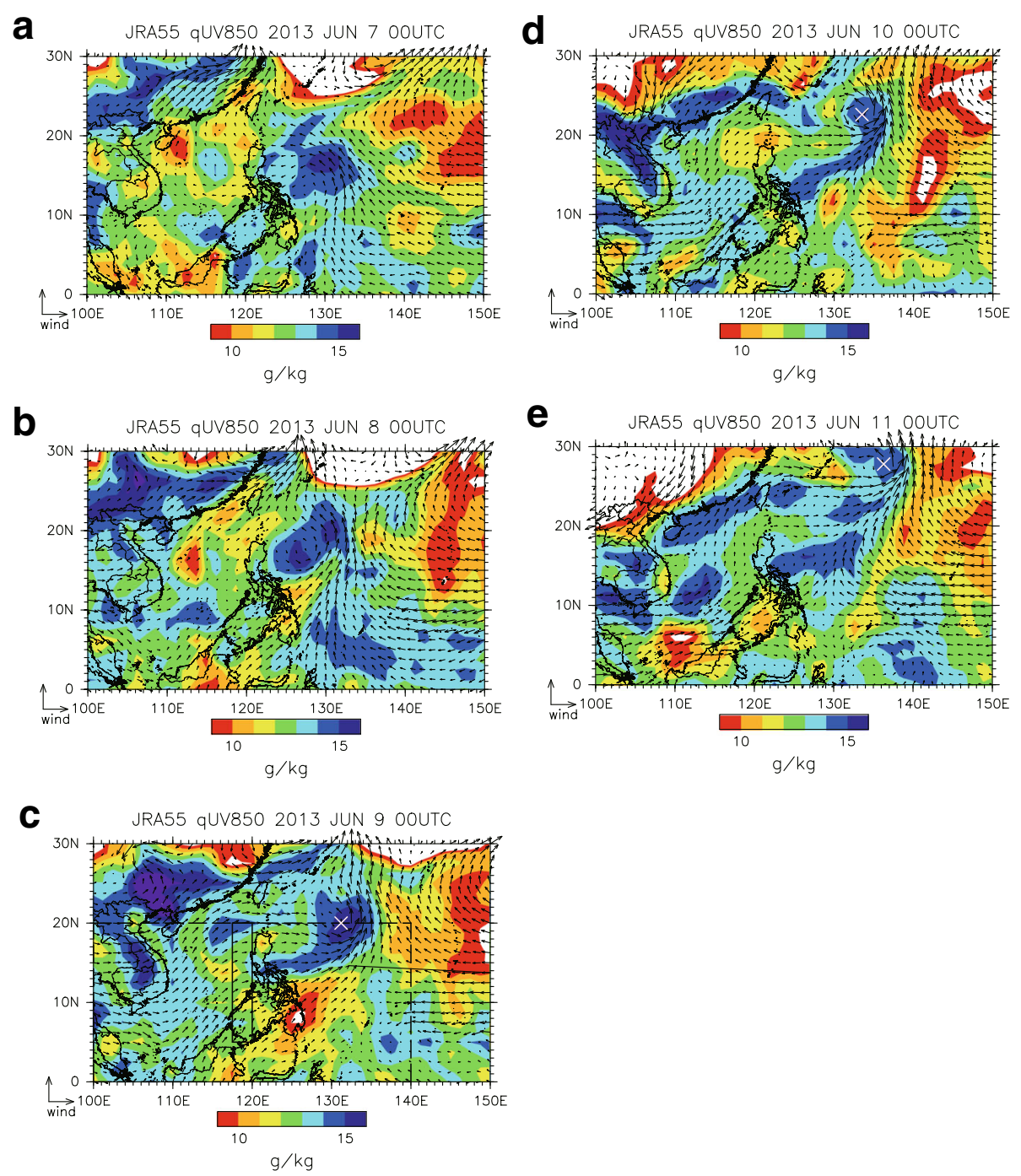

Fig. 10 Horizontal structure of water vapor mixing ratio (shading; g/kg) and wind (vector) at $850 \mathrm{hPa}$ from June 7 (a) to 11 (e), 2013. Unit vectors represent $25.0 \mathrm{~m} / \mathrm{s}$. Crosses indicate the centers of a tropical storm. Solid and dashed boxes in c are the cross-sectional area used in Fig. 9 and the area used to calculate PTCe

$\operatorname{PTCe}(i)=\frac{1}{11} \sum_{i-5^{i+5}} \mathrm{TC}(i)$

where $i$ is from 1956 to 2008 , and $\mathrm{TC}(i)=1$ if a TC existed in year $i$ or 0 if not.

The above expression has a range from 0 to 1 . The former indicates no existence of TC during the Philippine summer monsoon onset, while the latter signifies the occurrence of TC in every year of an 11-year sliding window. From the mid-1990s, PTCe increased during summer monsoon onset, and it exceeded 60\% (0.6) in the mid-2000s. The period of high PTCe during summer monsoon onset was concurrent with the period of early monsoon onset (Fig. 12). The correlation coefficient for PTCe and monsoon onset date in the 11-year running mean reached -0.84 at the $99 \%$ confidence level. A recent active TC in the PS and the SCS in May and June contributes to early Philippine summer monsoon onset. This suggests our case study of 2013 captured the typical summer monsoon onset conditions of recent years. Kajikawa and Wang (2012) suggested that TC became active in May after the mid-1990s. Before the mid-1990s, the PTCe was small, and TC did not act as the primary trigger for monsoon onset. When there was no TC near the Philippines during summer monsoon onset, a front was located north of the Philippines, and the southwesterly wind converged into the zonal front as observed for 2010 (Fig. 13). Akasaka (2010) described several conditions of atmospheric circulation during the summer monsoon onset. The interdecadal variability of the 


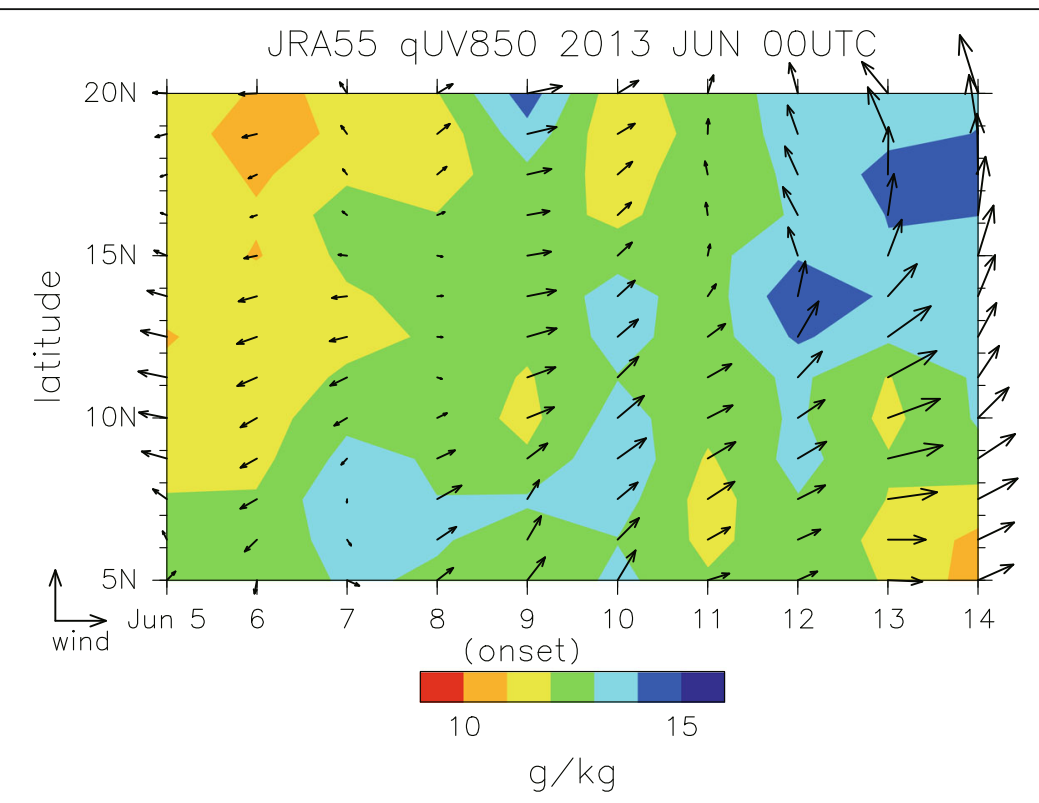

Fig. 11 Cross section $\left(5^{\circ} \mathrm{N} 20^{\circ} \mathrm{N}, 115^{\circ} \mathrm{E} 120^{\circ} \mathrm{E}\right.$ ) of water vapor mixing ratio (shading; g/kg) and wind (vector) at $850 \mathrm{hPa}$ during June 5-14, 2013. Unit vectors represent $10.0 \mathrm{~m} / \mathrm{s}$

Philippine summer monsoon onset date is strongly affected by TC activity in the PS and the SCS in May and June. The cause of this interdecadal variability of TC activity will be the subject of future work.

\section{Discussion}

Tanaka (1997) noted a delay of summer monsoon onset during El Niño decaying years. However, our longterm dataset demonstrated that the correlation between Philippine summer monsoon onset and the ENSO was significant only during the 1970s to the 1980s. The relationship of SCS SST and the ENSO also showed the highest correlation during the 1970s and the 1980s, as shown in Fig. 4 of Yang et al. (2015). The interdecadal variability of the relationship of SCS SST and the ENSO may influence the interdecadal variability of the relationship of the Philippine summer monsoon onset date and the ENSO.

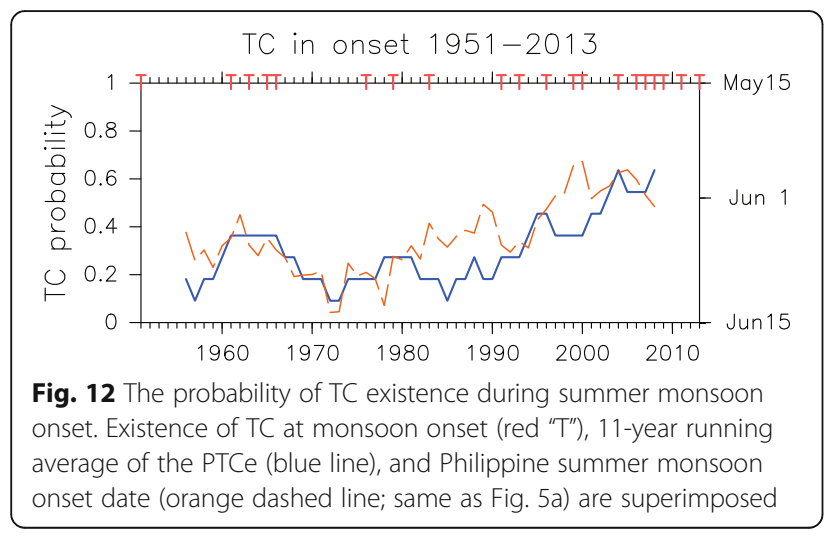

To identify atmospheric structures that trigger summer monsoon onset, we focused on the case of 2013 using a combination of intensive upper-air observations and a reanalysis dataset. The summer of 2013 was the first time that comprehensive upper-air observations were conducted in the Philippines since 1991. The interruption of observation was due to the eruption of Mt. Pinatubo in 1991. In 2013, TC Yagi traveled northward, east of the Philippines, and triggered the Philippine monsoon onset. Moist southwesterly wind was induced in the southwestern Philippines after the monsoon onset, and low-level southerly wind intensified after the monsoon onset with sudden moistening in the northern

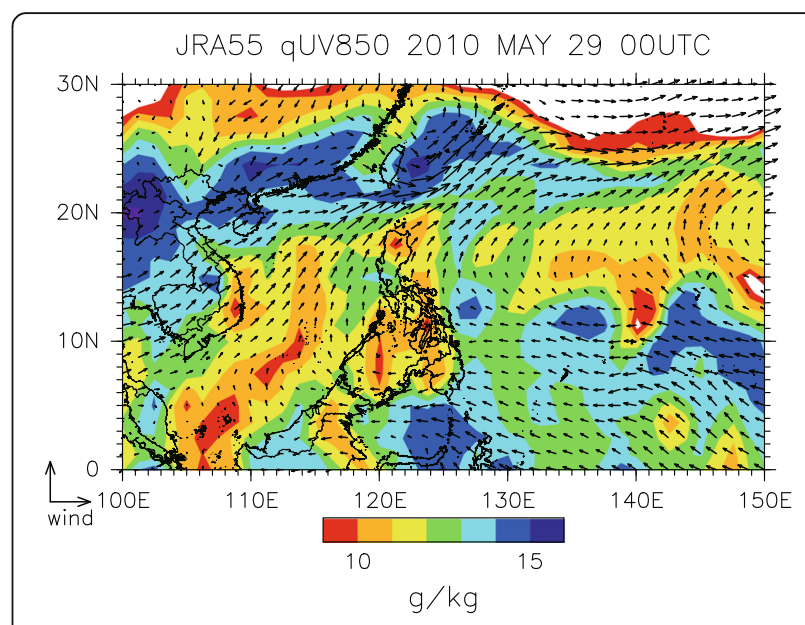

Fig. 13 Horizontal structure of moisture (shading; $\mathrm{g} / \mathrm{kg}$ ) and wind (vector) at $850 \mathrm{hPa}$ on May 29, 2010. Unit vectors represent $25.0 \mathrm{~m} / \mathrm{s}$ 
Philippines. In the climatology analysis, the summer monsoon onset started at the same time in the western Philippines. However, in situ observations demonstrated that when TC triggered the monsoon onset, the moistening process and prevailing wind direction differed between the southern and northern Philippines.

However, the role of TC activity decreased during late summer monsoon onset. Additionally, the historical TC dataset from Kubota (2012) shows high PTCe during the 1910s and the 1920s, which coincide with early summer monsoon onset (not shown). Further investigation is needed to verify the quality of the historical TC dataset. This study demonstrates the importance of historical station data in understanding interdecadal variability during the past 100 years.

\section{Conclusions}

The seasonal variation of Philippine rainfall associated with monsoons was investigated. Climatologically, Philippine rainfall increased on the west side of the country during June to October, associated with the summer monsoon, and rainfall increased from October to March on the eastern side, associated with winter monsoons that started in the northern Philippines and propagated southward. Withdrawal of winter monsoon rainfall occurred in December in northern Luzon Island and tended to be delayed moving south.

The long-term variability of summer monsoon onset in the Philippines was investigated using daily rainfall data for 1903-2013. Philippine summer monsoon onset is defined using the rainfall data of eight northwestern stations. The summer monsoon tended to start earlier in May after the mid-1990s. Other early northwestern stations. The summer monsoon tended to start earlier in May after the mid-1990s. Other early of summer monsoon onset was thus identified. Independent surface wind data from ships along the SCS revealed a prevailing westerly wind in May, consistent with early onset before 1940 and after the 1990s.

The influence of TC activity on the variability of summer monsoon onset date was investigated. From the mid-1990s, the probability of TC existence (PTCe) during the summer monsoon onset increased and became more than $60 \%(0.6)$, and is correlated with that period having an early monsoon onset. The PTCe was significantly correlated with the monsoon onset date in the Philippines. The recent early monsoon onsets observed after the mid-1990s were influenced by active TC formation in the PS and the SCS. Tropical cyclone activity in the PS and the SCS plays a key role in initiating early Philippine summer monsoon onset.

\section{Abbreviations}

ENSO: El Niño-Southern Oscillation; HadISST: Hadley Center Global Sea Ice Sea Surface Temperature; ICOADS: The International Comprehensive
Ocean-Atmosphere Dataset; IO: Indian Ocean; JRA55: Japanese 55-year reanalysis; JTWC: Joint Typhoon Warning Center; NAIA: Ninoy Aquino International Airport; OLR: Outgoing longwave radiation; PAGASA: Philippine Atmospheric Geophysical and Astronomical Services Administration; PALAU: Pacific Area Long-term Atmospheric observation for Understanding climate change; PJ: Pacific-Japan; PS: Philippine Sea; PTCe: Probability of TC existence; SCS: South China Sea; SST: Sea surface temperature; TC: Tropical cyclone; WNP: Western North Pacific

\section{Acknowledgements}

The PALAU 2013 observation project was conducted under the Implementation Agreement between PAGASA and JAMSTEC. We wish to thank Dr. Ikumi Akasaka of Senshu University and Prof. Masumi Zaiki of Seikei University for collecting the Philippine Weather Bureau station data; Mr. Yoshio Shinohara of the Japan Meteorological Agency for sharing the historical bulletins of the Central Meteorological Observatory of Tokyo, Japan; and Dr. Hiroki Tokinaga of Kyoto University for providing the surface wind dataset of the South China Sea. JM and HK were supported by "Global Environment Research Fund from the Ministry of the Environment Japan" B061, "Data Integration \& Analysis System," "Green Network of Excellence" (GRENE), "Program for Risk Information on Climate Change" (SOUSEI), and Grant-in-Aid for Scientific Research No. (25282085, 15KK0030; PI HK), No. (2024007, 23240122, and 26220202; PI: JM), No. 16H04053, No. $16 \mathrm{H03116}$ and Young Scientific Research No. (21684028; PI HK) was funded by the Japan Society for the Promotion of Science (JSPS). This research was also supported by the Science and Technology Research Partnership for Sustainable Development (SATREPS), Japan Science and Technology Agency (JST)/Japan International Cooperation Agency (JICA).

\section{Funding}

JM and HK were supported by the Global Environment Research Fund from the Ministry of the Environment Japan B-061, the Data Integration \& Analysis System, Green Network of Excellence (GRENE), the Program for Risk Information on Climate Change (SOUSEI), and Grant-in-Aid for Scientific Research (No. 25282085, 15KK0030; PI HK), (No. 2024007, 23240122, and 26220202; Pl: JM), No. 16H04053, No. $16 \mathrm{H} 03116$ and Young Scientific Research (No. 21684028; PI HK), funded by the Japanese Society for the Promotion of Science (JSPS). This research was also supported by the Science and Technology Research Partnership for Sustainable Development (SATREPS), the Japanese Science and Technology Agency (JST), and the Japanese International Cooperation Agency (JICA).

\section{Authors' contributions}

HK proposed the topic and conceived and designed the study. HK, RS, EC, and FH carried out the intensive observations and obtained the dataset for this study with the cooperation of JAMSTEC and PAGASA. JM, EC, and FH collaborated with the corresponding author and contributed to the interpretation of the monsoon period. All authors read and approved the final manuscript.

Ethics approval and consent to participate Not applicable

\section{Consent for publication}

Not applicable

\section{Competing interests}

The authors declare that they have no competing interests.

\section{Publisher's Note}

Springer Nature remains neutral with regard to jurisdictional claims in published maps and institutional affiliations.

\section{Author details}

${ }^{1}$ Faculty of Science, Hokkaido University, Kita 10 Nishi 8, Kita-ku, Sapporo 060-0810, Japan. ${ }^{2}$ Department of Coupled Ocean-Atmosphere-Land Processes Research, Japanese Agency for Marine-Earth Science and Technology (DCOP, JAMSTEC), Yokosuka, Japan. ${ }^{3}$ Department of Geography, Graduate School of Urban Environmental Sciences, Tokyo Metropolitan University, Tokyo, Japan. ${ }^{4}$ Philippine Atmospheric, Geophysical and Astronomical Services Administration (PAGASA), Quezon City, Philippines. 
Received: 5 June 2016 Accepted: 18 August 2017

Published online: 27 September 2017

\section{References}

Akasaka I (2010) Interannual variations in seasonal march of rainfall in the Philippines. Int J Climatol 30:1301-1314

Akasaka I, Morishima W, Mikami T (2007) Seasonal march and spatial difference of rainfall in the Philippines. Int J Climatol 27:715-725

Cayanan EO (2010) A study of heavy rainfall events during the southwest monsoon season in the Philippines. Dissertation, University of the Philippines

Cayanan EO, Chen TC, Argete JC, Yen MC, Nilo PD (2011) The effect of tropical cyclones on southwest monsoon rainfall in the Philippines. J Meteor Soc Japan 89A:123-139

Chang CP, Zhang Y, Li T (2000a) Interannual and interdecadal variations of the east Asian summer monsoon and tropical Pacific SSTs. Part I: roles of the subtropical ridge. J Clim 13:4310-4325

Chang CP, Zhang Y, Li T (2000b) Interannual and interdecadal variations of the east Asian summer monsoon and tropical Pacific SSTs. Part II: meridional structure of the monsoon. J Clim 13:4326-4340

Chen TC, Tsay JD, Yen MC, Cayanan EO (2010) Formation of the Philippine twin tropical cyclones during the 2008 summer monsoon onset. Wea Forecasting 25:1317-1341

Chowdary JS, Xie SP, Tokinaga H, Okumura YM, Kubota H, Johnson N, Zheng XT (2012) Interdecadal variations in ENSO teleconnection to the Indo-Western Pacific for 1870-2007. J Clim 25:1722-1744

Deppermann CE (1939) Some characteristics of Philippine typhoons. Weather Bureau Manila Central Observatory

Durre I, R. Vose RS, Wuertz DB (2006) Overview of the integrated global radiosonde archive. J Clim 19:53-68

Ebita A, Kobayashi S, Ota Y, Moriya M, Kumabe R, Onogi K, Harada Y, Yasui S, Miyaoka K, Takahashi K, Kamahori H, Kobayashi C, Endo H, Soma M, Oikawa Y, Ishimizu T (2011) The Japanese 55-year reanalysis 'JRA-55': an interim report. SOLA 7:149-152

Flores JF, Balagot VF (1969) Climate of the Philippines. Climates of northern and eastern Asia. In: Arakawa H (ed) World survey of climatology, vol 8. Elsevier, Amsterdam, pp 159-213

Hattori M, Matsumoto J, Ogino SY, Enomoto T, Miyoshi T (2016) The impact of additional radiosonde observations on the analysis of disturbances in the South China Sea during VPREX2010. SOLA 12:75-79

Kajikawa Y, Wang B (2012) Interdecadal change of South China Sea summer monsoon onset. J Clim 25:3207-3218

Kobayashi S, Yamamoto H (2013) Wartime meteorological observations of the Japanese military in East Asia and the collection of its neglected data. Hist Geogr 267:82-98

Kubota H (2012) Variability of typhoon tracks and genesis over the Western North Pacific. In: Oouchi K, Fudeyasu H (eds) Cyclones: Formation, Triggers and Control, Nova Science Publishers, Inc., pp 95-114

Kubota H, Shirooka R, Ushiyama T, Chuda T, Iwasaki S, Takeuchi K (2005) Seasonal variations of precipitation properties associated with monsoon over Palau in the western Pacific. J Hydrometeorol 6:518-531

Kubota H, Kosaka Y, Xie SP (2016) A 117-year long index of the Pacific-Japan pattern with application to interdecadal variability. Int J Climatol 36:1575-1589

Kubota H, Wang B (2009) How much do tropical cyclones affect seasonal and interannual rainfall variability over the western North Pacific? J Clim 22:5495-5510

Lau KM, Yang S (1997) Climatology and interannual variability of the southeast Asian summer monsoon. Adv Atmos Sci 14:141-162

Lyon B, Camargo SJ (2008) The seasonally-varying influence of ENSO on rainfall and tropical cyclone activity in the Philippines. Clim Dyn doi https://doi.org/ 10.1007/s00382-008-0380-z

Lyon B, Cristi H, Verceles ER, Hilario FD, Abastillas R (2006) Seasonal reversal of the ENSO rainfall signal in the Philippines. Geophys Res Lett 33:L24710. https://doi.org/10.1029/2006GL028182

Matsumoto J (1997) Seasonal transition of summer rainy season over Indochina and adjacent monsoon region. Adv Atmos Sci 14:231-245

Murakami T, Matsumoto J (1994) Summer monsoon over the Asian continent and western North Pacific. J Meteor Soc Japan 72:719-745

Nitta T (1987) Convective activities in the tropical western Pacific and their impacts on the Northern Hemisphere summer circulation. J Meteor Soc Japan 65:165-171

Ramage CS (1971) Monsoon Meteorology, Academic Press, New York
Rayner NA, Parker DE, Horton EB, Folland CK, Alexander LV, Rowell DP, Kent EC, Kaplan A (2003) Global analyses of sea surface temperature, sea ice, and night marine air temperature since the late nineteenth century. J Geophys Res 108(D14):4407. https://doi.org/10.1029/2002JD002670

Ropelewski CF, Halpert MS (1987) Global and regional scale precipitation patterns associated with the El Niño/ Southern Oscillation. Mon Wea Rev 115:1606-1626

Saunders MA, Chandler RE, Merchant CJ, Roberts FP (2000) Atlantic hurricanes and NW Pacific typhoons: ENSO spatial impacts on occurrence and landfall. Geophys Res Lett 27:1147-1150

Sola MSJ (1903) Report of the Director of the Philippine Weather Bureau 1902 part II: meteorological service of the Philippine islands, Report of its establishment and development under the Spanish government and its reorganization under the government of the United States (1865-1902). Bureau of Public Printing, Manila

Tanaka M (1992) Intraseasonal oscillation and onset and retreat dates of the summer monsoon over east, southeast Asia and the western Pacific region using GMS high cloud amount. J Meteor Soc Japan 70:613-629

Tanaka M (1997) Interannual and interdecadal variations of the western north Pacific monsoon and Baiu rainfall and their relationship to the ENSO cycles. J Meteor Soc Japan 75:1109-1123

Tokinaga H, Xie SP (2011) Wave- and anemometer-based sea surface wind (WASWind) for climate change analysis. J Clim 24:267-285

Udias A (1996) Jesuits' contribution to meteorology. Bull Am Meteorol Soc 77: $2307-2315$

Villafuerte MO II, Matsumoto J, Akasaka I, Takahashi H, Kubota H, Cinco TA (2014) Long-term trends and variability of rainfall extremes in the Philippines. Atmos Res 137:1-13

Wang B (2006) The Asian Monsoon. Springer Praxis Publishing, New York

Wang B, LinHo (2002) Rainy seasons of the Asian-Pacific monsoon. J Clim 15: 1071-1085

Wang B, Wu R, Fu X (2000) Pacific-East Asian teleconnection: how does ENSO affect East Asian climate? J Clim 13:1517-1536

Wang XL, Feng Y (2013) RHtests_dlyPrcp user manual. Climate Research Division, Atmospheric Science and Technology Directorate, Science and Technology Branch, Environment Canada, http://etccdi.pacificclimate.org/software.shtml. Accessed 7 Aug 2017

Wang XL, Chen H, Wu Y, Feng Y, Pu Q (2010) New techniques for detection and adjustment of shifts in daily precipitation data series. J Appl Meteorol Climatol 49:2416-2436. https://doi.org/10.1175/2010JAMC2376.1

Woodruff SD, Worley SJ, Lubker SJ, Ji Z, Freeman JE, Berry DI, Brohan P, Kent EC, Reynolds RW, Smith SR, Wilkinsond C (2011) ICOADS release 2.5: extensions and enhancements to the surface marine meteorological archive. Int J Climatol 31:951-967

Xie SP, Hu K, Hafner J, Tokinaga H, Du Y, Huang G, Sampe T (2009) Indian Ocean capacitor effect on Indo-western Pacific climate during the summer following El Nino. J Clim 22:730-747

Yang Y, Xie SP, Du Y, Tokinaga H (2015) Interdecadal difference of interannual variability characteristics of South China Sea SSTs associated with ENSO. J Clim 28:7145-7160

\section{Submit your manuscript to a SpringerOpen ${ }^{\circ}$ journal and benefit from:}

- Convenient online submission

- Rigorous peer review

- Open access: articles freely available online

- High visibility within the field

- Retaining the copyright to your article

Submit your next manuscript at $>$ springeropen.com 